\title{
Nursing networks: strategies to strengthen research and extension studies
}

\section{Cristianne Maria Famer Rocha ${ }^{a}$ Silvia H. De Bortoli Cassiani ${ }^{b}$}

D0l: http://dx.doi.org/10.1590/19831447.2015.02.56420

In recent decades, health care networks in different parts of the world have incorporated new forms of social organization that involve extensive use of technology to produce and disseminate information and are based on the autonomous, non-hierarchical and decentralized cooperation and collaboration of those within these networks.

In Latin American countries, Nursing Networks were created in the 2000s on the initiative of professionals seeking to exchange knowledge and experiences. Over time this initiative gained ground with the support and leadership of the Regional Council for Nursing and Health Technicians of the Pan American Health Organization (PAHO) and, in 2007 and, in 2007, the $1^{\text {st }}$ International Nursing Network Conference was held in Toledo (Spain), during the $9^{\text {th }}$ Ibero-American Conference of the Latin American Association of Nursing Schools (ALADEFE).

These networks operate as a communication strategy, stimulating cohesion and cooperation between nurses interested in developing nursing care, management, research, information and education with a view to supporting the advancement of the profession and help countries achieve universal health care coverage and access to health services.

There are currently around 25 International Nursing Networks in the Americas, which together form Rede EnfAmericas and consist of more than 3000 nurses in Latin America. Information on each of these networks is available at: http://www. observatoriorh.org/?q=node/562

The objectives of Rede EnfAmericas include strengthening the development of multicenter trials in order to share information, knowledge and scientific evidence, technological resources and methods aimed at Nursing care, management, teaching, research, information and technical cooperation and their contribution to other fields of knowledge ${ }^{(1)}$. Given that most of the members of International Nursing Networks are professors ${ }^{(2)}$, many of the activities performed are aimed at developing collaborative research and international reach. However, not all the networks are using these strategies to their full potential.

Some International Nursing Networks have already identified the need for greater cohesion among national and international participants, with a view to conducting larger and more effective exchanges and producing common knowledge. However, although Brazil has a large number of active National Networks(2), the country has found it difficult to carry out joint activities or collaborate outside national territory. The size of the country, its geographic position and language barriers are significant obstacles to greater approximation; however, efforts must be made to favor the creation of sharing mechanisms with people, groups, organizations and institutions that produce knowledge on national and international topics of interest to the field of Nursing.

Cassiani et al.(3) identify priorities and make recommendations that could may benefit the planning, development, monitoring and assessment of work conducted by and within these networks. Among the recommendations made are:

1. Develop research on staff shortages, distribution and qualification in Nursing;

2. Implement integration strategies for Nurses working in Network health care services;

3. Encourage the participation of countries that do not yet have Networks;

a PhD in Education, Professor at the School of Nursing of the Federal University of Rio Grande do Sul, Coordinator of the Nursing Communication Network (ReCEn) supported by the Pan-American Health Organization (OPAS/WHO). ${ }^{b}$ PhD in Nursing, Regional Advisor for Nursing and Health Technicians of the Pan-American Health Organization (PAHO/WHO). This author is a member of the Pan-American Health Organization/World Health Organization. She is responsible for her opinion expressed in this article, which does not necessarily reflect the decisions or policies of the Pan-American Health Organization/World Health Organization. 
4. Create websites (or other media) and encourage the use of social media;

5. Promote extension activities.

Achieving visibility for International Nursing Networks initiatives remains a challenge for everyone involved. Information and communications technology needs to be more widely used to publicize the products and contribution of these Networks and advance Nursing knowledge and practice.

Nevertheless, the greatest strengths of these Networks lie in the opportunity to exchange experiences and different types of knowledge, as well as strengthening the ties between its members in a multicultural and collaborative environment.

It is up to the PAHO/WHO to coordinate, support and monitor the organization of nurses into networks in order to advance health care and promote regional visibility for the work of International Nursing Networks and nurses in particular.

\section{QREFERENCES}

1. Mendes EV. As redes de atenção à saúde.Brasília: OPAS; 2011.

2. Observatório Regional de Recursos Humanos en Salud [Internet] Wahington; c2012-2015 [acesso 10 out 2014]. Objetivos de la red de enfermería; [1 tela]. Disponível em: http://www.observatoriorh.org/?q=node/566. Acesso em: 10 out. 2014.

3. Cassiani SHB, García AB, Cabalero E, Jiménez MA, Esperón JMT, Osegueda E, et al. Redes internacionales de enfermería de las Américas: trabajo colaborativo para el logro de la cobertura universal en salud. Enfermería (Montev.).2014 jun;3 (1):42-54. 